\title{
1989, THE YEAR THAT NEVER ENDED: EPISTEMOLOGY AND METHODOLOGY OF THE RESEARCH IN Political Communication in Brazil
}

\author{
Francisco Paulo Jamil Marques \& Edna Miola
}

\begin{abstract}
This paper examines a relevant part of the Brazilian scientific production in Political Communication in order to assess the epistemological and methodological advances and flaws that have featured this area of expertise. The argument is divided into four parts. In the first one, we discuss different theoretical questions, ranging from the imprecision in the definition of objects and categories of research to a persistent conceptual outdatedness. Next, the text focuses on some of the most common methodological options found in empirical studies present in the field, diagnosing the predominance of a descriptive emphasis. The third section reflects on the consequences of the burdens previously pointed out: for example, research findings that tend to overestimate media effects. We conclude our argument by addressing some suggestions that may help to solve part of the problems here outlined.
\end{abstract}

\section{KeYwORDS}

Communication; epistemology; methodology; politics

\begin{abstract}
RESUMO
Este trabalho examina o perfil de parte relevante da produção científica da área de Comunicação e Política no Brasil a fim de elaborar um balanço acerca dos avanços e dos entraves epistemológicos e metodológicos comuns às abordagens investigativas mais recorrentes no país. $\mathrm{O}$ argumento está dividido em quatro partes. Na primeira delas, discutem-se problemas de fundo teórico, apontando-se desde a imprecisão na definição dos objetos até certa desatualização conceitual. Em seguida, a proposta se debruça sobre as falhas que caracterizam algumas das opções metodológicas mais empregadas em pesquisas da área. A terceira seção avalia as consequências dos estorvos anteriormente verificados, mencionando-se, por exemplo, a tendência a elaborar generalizações equivocadas sobre os efeitos políticos da mídia. O texto é encerrado com um tópico disposto a endereçar sugestões que podem colaborar na resolução de parte dos problemas aqui tratados.
\end{abstract}

\section{INTRODUÇÃo}

This article aims to examine the profile of a relevant part of the Brazilian scientific production in Political Communication to develop a panorama of its main epistemological and methodological advances and barriers. The idea is to privilege the most recurrent 
investigative approach in this country. We advocate that mapping the emphases on the main studies after the presidential run in 1989 is necessary to identify the methodologi$\mathrm{cal}$ and epistemological challenges that have marked the interface between Communications and Politics in the Brazilian context.

More specifically, we aim to investigate the impression that the advances witnessed on the theoretical-methodological dimensions seem to be relatively timid in this field. For example, almost 30 years after the elections that led Fernando Collor to the Presidency of Brazil, some of the most recent works keep analyzing the journalistic coverage of elections by using the very same lenses that characterized the research on the 1990's.

The year of 1989 is particularly relevant to the Brazilian democracy and to the studies on the area in focus since the last national elections before that opportunity had taken place only in 1960. During this interval, Brazil experienced significative technological advances on its broadcast communications (improving the country's capacity of reaching even regions distant from the main cities), which have established new ways of politicalelectoral sociability. Thus, the redemocratization imposed to the 22 candidates the need to adapt to a new audiovisual grammar, forcing them to take part in electoral debates, opinion polls, and to deal with marketing consultants (Albuquerque, 1999; Carvalho, 1999). We may add to these factors the exhibition of an edited version of the presidential debate between Lula and Collor on the TV channel "Clobo", which catalyzed a wave of studies that brought relevance to the area of Political Communication in Brazil (Weber, 1990). We can say that a new research agenda was proposed from that year thanks to the work of scholars prone to go beyond the idea of political communication as a governmental agenda - a predominant perspective until then due to the rules and censorship imposed by the Military Regime (Lima, 1997).

Although those elections happened almost three decades ago, the perception that advances on the research seem to be limited is spread to different sub-areas of knowledge associated to the field of investigations at stake. As an illustration, if we consider the studies on Political Journalism in Brazil, it is possible to say that a noticeable amount of literature keeps treating agents and phenomena as if the political and media landscapes were the same as those of Collor's election, in 1989. A set of different evidences points out that the news activity has changed since then (Guerra, 2014). As example of these signs we can remind that Globo Organizations do not have the same influence power than it had in that decade (Sampaio, 2010) due to 1) - changes in the consumption of political information; 2) - transformations in the patterns of electoral coverage practiced by this media group (Rede Globo, 2018); or 3 ) the competition between journalism and social media (Canavilhas, 2010). Moreover, the ways of conducting an electoral campaign since then have also changed (Gomes, 2004). From an institutional perspective, the Brazilian State is continuously changing (Bresser-Pereira, 2017). A portion of the scientific production, however, stays connected to references that lack theoretical, methodological and epistemological update. It is what we propose to discuss here.

Before proceeding to the main argument, we make some cautious notes. Firstly, it is reasonable to admit that this is an incomplete diagnosis. Even though this proposal 
has no experimental-quantitative approach (on the contrary, it is a reflexive work), the text needs to face the indictment that it suffers from limitations when it does not revise completely what has been produced over the last 30 years - indeed, it would be an impossible task due to the growing flow of scientific production. Therefore, we avoid generalizing the diagnosis.

However, even though we do not set a precisely delimited corpus, it is possible to clarify the kind of scientific production that was taken in account in this article. There are four main sources that allowed us to enumerate the tendencies of investigation in Political Communication in Brazil. The first of them concerns the proceedings of the Specialist Group (SG) in "Communication and Politics" of the Brazilian National Association of Post-Graduate Programs in Communication (Compós), which exists since 1992. This group annually debates 10 texts, which assemble about 250 texts by 2018 . Researchers from diverse institutions - many of them traditional researchers who have formed new generations of scholars - have coordinated this space for debate, which works like a sounding board that aggregates researchers from the fields of communication, political science, among others.

The second source covers the works presented on the SGs of the National Association of Post-Graduate Studies and Research in Social Sciences (ANPOCS). Its annual conference offered one of the first opportunities to discuss the area of Political Communication in 1994, in a session named "Media and citizenship" hosted at the SG "Political Culture". In 1996, it was the time for the SG "Political parties and Electoral behavior" to propose a session named "Media, political socialization and disbelief". Only in 1997, however, ANPOCS started to maintain a permanent space to the authors connected to Political Communication, even if the name of the session has varied over time. The SG was named as "Media, Politics and Public opinion" when it first appeared; "Media, Public Opinion and elections", in 2000; "Democracy, Political communication and elections", in 2004 and 2009; "Media, politics and elections", in 2008.

The third dataset able to allow us to sketch a panorama of this expertise is the Directory of Dissertations and Theses of the Brazilian Association of Researchers in Communication and Politics, whose catalog has around 500 works (Compolítica, 2018). The repository is divided into nine themes (from Journalism to Political Marketing, for example) and allows us to know institutions, researchers and indicators of production - items that were studied in articles previously published, e.g. Aldé, Chagas e Santos (2013), and Santos, Aldé e Schwambach (2016).

Finally, it is possible to point out a range of books that featured some of the tendencies of the Brazilian scientific production in Political Communication - mainly because they involve researchers who still have a leadership in the area. Illustratively, we may mention the book Media, elections, and democracy, organized by Heloiza Matos in 1994; the book Communication and politics: concepts and approaches, published under the responsibility of Albino Rubim in 2004 and critically reviewed by João Carlos Correia (2005) as representative of the national production; and Media, representation, and democracy, organized by Luis Felipe Miguel and Flávia Biroli, in 2010. 
Even though 1) these sources are not approached empirically in this article, 2) the knowledge of them do not allow us to generalize conclusions for all the field of research, and 3) we consider legitimate these and other reservations to our work, we defend the importance of the argument outlined in this text. The article brings to the debate an array of considerations on the progress and the problems that make difficult to rise the impact factor of the Brazilian publications. Indeed, this burden constitutes one of the most relevant embarrassments in the area of Communication and Information pointed out by the Quadrienal Evaluation Report 2017 launched under the responsibility of the CAPES Foundation. Thus, we support the idea that by considering this contribution the reader will have the opportunity of identifying (and avoiding) some obstacles when conducting his own projects on Political Communication.

Moreover, we want to clarify that, contrarily to the proposal of Alan Sokal and Jean Bricmont (2010), in the book Intellectual impostures, the idea of this article is absolutely not to denounce 'abuses' (sic) - although the question of the epistemic relativism highlighted by these authors represents a focus of restlessness, as explained further up. By the way, we do believe that the authors or the works we mention do not have the intention to deceive the reader. Our single aim is to put in question the embarrassments that may compromise the accumulation of knowledge in our field of studies. In other words, our goal is to stress some analytical problems that until now have not been object of reflection. We opted then for illustrating some of the works affected by the problems we diagnose. Once more, we decided to do this taking into account that there would not be any advantage to generate misunderstandings in personalizing the critics, since the target is to explore elements that seem to have a broader reach than a work of a group or a single institution.

We can assure, however, that the questions pointed out in this proposal do not constitute exceptions. This idea can be testified from at least three sources: the first one consists in questioning the analyses covered by chapters published over the last years - among them Rubim (2004), as mentioned before; the second evidence is the evaluation on the Communication research area provided by the CAPES Foundation (Brazilian Ministry of Education). Lastly, this article dialogues with other researches who share the same concerns as ours.

The text is divided into four parts. In the first one, we discuss a diverse array of theoretical questions, ranging from the imprecision in defining objects and categories of research to a persistent conceptual outdatedness. Next, the article focuses on some of the most common methodological options found in empirical studies in the field, diagnosing the predominance of a descriptive emphasis. The third section reflects on the consequences of the burdens previously pointed out: for example, the salience of research findings that tend to overestimate media effects. The conclusion addresses some suggestions that may help to solve part of the problems here outlined. 


\section{THEORETICAL DIFFICULTIES}

\section{THE TERMINOLOGICAL IMPRECISION}

The area of Political Communication, by its history and legacy, brings together investigations of diverse natures. It is possible to focus the studies in different moments of the political life of societies (during mandates, elections or institutional crises); to emphasize the content of messages published on certain medium (television, radio, printed material and digital devices); to give attention to how the media mobilize political actors (elected representatives, candidates, social movements, communication consultants, journalists); or, in a broadly manner, to research the various social activities that involve the media and democracy (like the state's performance in regulating the communication market) (Albuquerque, 2013; Coelho \& Locatelli, 2017; Gomes \& Maia, 2008; Maia, 2012; Miguel \& Biroli, 2010; Rubim, 2004; Weber, 1990).

Thus, the opportunity to associate platforms, agents and activities gives the scholars of this area of expertise the advantage of having at hand an almost inexhaustible source of research topics.

At the same time, such a profusion of options may imply difficulties in enclosing more clearly the objects of study. In other words, if we are blessed by the advantages the interdisciplinarity brings to the Media Studies, one cannot ignore the preoccupation with the terminological inaccuracies that feature part of our production. If we take the idea of "public sphere" (Habermas, 1984) as an example, it will be possible to verify that the movement dedicated to loosing this concept in order to encompass a plurality of phenomena and environments may end up provoking exactly its uselessness (Marques, 2006; Miola, 2009). A similar situation occurs to the concepts of "power" or "spectacularization" (Chaui, 2006; Guareschi, 1994); moreover, the definition of "public interest" sometimes adopts conflicting perspectives when it designates experiences of Public Communication (Duarte, 2012; Matos, 2012; Paulino, Guazina \& Oliveira, 2016).

Notwithstanding, it has to be emphasized this kind of terminological imprecision is not only a mark of the subarea of Political Communication. According to Moragas:

the story of investigation about mass communication makes it clear that the assignments that intend to constitute this work in an "independent" discipline, homologous in status to the social sciences, have proved to be a very unprofitable task for the development or progress of knowledge about our object of study, which is always difficult to delimit. (1981, p. 12)

The point is that, in the Brazilian studies of Political Communication, it is frequent the use of macrocategories that end up generating more doubts than clarifications when they are used to explain different phenomena. If "media" or "hegemonic media" remain terms that are often used as synonyms, the reader must notice that a closer observation reveals a terminological confusion.

Objectively, the conceptual disorder surrounding, for example, the notion of "media" has not yet been completely overcome. The term may designate a device for data storage (Figueiredo \& Mendes, 2015); a communication channel through which the 
message is transmitted (Peruzzo, 2003); an area of activity in an advertising agency (Giacomini Filho, 2013); or agents related to the field of Journalism (Fernandes \& Correia, 2014). The indiscriminate use of the term "media" thus leaves in the background all the wealth of phenomena, services, interests, markets, professionals, deontologies, technologies, techniques and practices that encompasses contemporary mass communication (Citelli, Berger, Baccega, Lopes \& França, 2014). When the analyses fail regarding conceptual caution - insisting on considering with the same investigative lens (under the umbrella "media") diverse activities -, it becomes natural to confuse means (in an instrumental-propagandistic perspective), on the one hand, and institutions, on the other. If we speculate that such distinctions are clearly established in the authors' minds, it may be necessary to work to improve the redactional dimension in our literature (Fausto Neto, 2004).

\section{OUTDATED LITERATURE}

In Brazilian papers in Political Communication, it is common to use classical concepts typical of Communication Theories. In principle, this would not be a problem, but we must acknowledge that, in different situations, theories and hypotheses of the 1970s are still presented in our research field as if they were recent.

Note, for example, even the case of those newer studies on agenda-setting (Gomes \& Torres, 2017). If, on the one hand, it is possible to argue that new communication channels introduce unprecedented possibilities for the agenda process (this is the case of flows involving social network sites), on the other hand, the starting questions and the empirical provision we deal with are very often limited to reproducing what has been done for decades (McCombs \& Shaw, 1972).

To be fair, it is wise to point out that a group of investigations published over the last decade has come to consider the concept of framing (also known as "second level of agenda-setting") (Liedtke, 2008) - although almost always reproducing, under different looks, what Gamson \& Modigliani (1989), Entman (1994) or Goffman (1986) developed - which are not necessarily recent references either.

In practice, different texts dedicated to frame studies adopt the following logic: introducing the reader to the methodological efforts elaborated by some of the pioneering authors' works; modeling the criteria of analysis by using categories that often overlap or employ a markedly subjective classification of frames - opening up space to controversies. In this sense, under the justification that each case is a different case, a zone of theoretical and methodological convenience is established, as if nothing had been improved since then. Exceptions can be found in Vimieiro \& Maia (2011) and Campos (2014), who adopt an interesting posture regarding the classical conceptual applications and that build an original empirical architecture. 


\title{
METHODOLOGICAL DIFFICULTIES
}

At the beginning of the 2000s, the area of Communication studies in Brazil was characterized by the difficulty in accumulating knowledge, given the fragilities of previous research. Whoever wanted to discover something new, would have to start practically from zero due to the methodological inconsistency of most of the studies elaborated until then. According to the representative of the area of Applied Social Sciences I in the Ministry of Education at that time:

\begin{abstract}
the mentality of our programs [postgraduate programs in communication], in general, lacks a clear and effective idea of cumulative research. Either they are unaware of the previous work or they are so unreliable in their results that our researchers are always starting again the work of producing knowledge about a topic or specialty. Then, it is practically impossible to stabilize a field of research with a sufficient volume of consolidated knowledge, i.e. tested, evaluated and accepted by the scientific community.
\end{abstract} (Gomes \& Moreira, 2000, p. 131)

In the specific case of studies in Political Communication, the numerical increase of researchers, as well as the mutual citation of works of the area, did not necessarily imply a noteworthy advance in methodological terms able to lead us to take part in intellectual clashes witnessed in international journals. This is what we discuss below.

\section{LITTLE IS INVENTED, BUT MUCH IS POORLY COPIED}

Communication studies are consolidated as an area of knowledge in Brazil since the second half of the twentieth century due to the increase in the number of undergraduate and postgraduate schools since then (Melo, 1999).

However, as we know, the act of claiming objects, theories, and research problems requires the development of unique research methodologies (Silva, 2009). This does not mean, of course, defending isolation in regard to the proposition or use of diverse investigative techniques.

Therefore, we argue that if, on the one hand, dialogue with analysis methods from other areas of knowledge is fundamental, on the other, a deep domain of such techniques is required - either to reproduce or to adapt them. Thus, we must say that not always the process of appropriating diverse methodologies has successful results.

Consider how some of the Brazilian works in Political Communication use content analysis (or the adoption of discourse analysis) - often ignoring particularities of the original areas which created such techniques. For example, using discourse analysis in conjunction with content analysis for treating the same corpus is criticized in a number of key references (Bardin, 2007; Charaudeau, 2006; Fairclough, 2001; Foucault, 1979; Orlandi, 2007; Pêcheux, 1988; Van Dijk, 2008).

Another example of the simple transposition of analytical techniques is found in Brazilian works aimed at investigating the idea of public deliberation (Seridorio \& 
Luvizotto, 2017). Although the theoretical models inspiring such a perspective (Bohman, 1996; Elster, 1998; Gutmann \& Thompson, 1996; Habermas, 1996) are often criticized due to their normative nature, national research often choose to apply a specific set of parameters (reflexivity, representativeness, reciprocity, among others), resulting in frustration with the research findings (researchers regret, for example, that, despite the discursive potential of online forums, citizens insist on attacking each other or remaining silent). This occurs not only because reality is different from the ideal models designed by researchers, but also because of the need to consider the influence of sociocultural contexts and specific political moments on the processes of political conversation. In a televised electoral debate, for example, agreeing with the adversary can increase the chances of losing votes (Marques, Vimieiro, Vieira \& Melo, 2009). In this sense, part of the investigations in our field (Sousa \& Marques, 2015, for example) points to contributions that merely illustrate (a) that each case is unique, (b) that public debate of good quality is difficult to happen (especially in competitive landscapes), and (c) that the analytical models elaborated are wrong if they try to make reality fit in categories elaborated with a theoretical-philosophical groundwork.

\section{TOO MUCH DESCRIPTION, TOO LITTLE HEURISTIC PROGRESS}

The consistency of an empirical study is revealed in the dimensions concerning the appropriateness of the collection and analysis methods, as well as the depth of the interpretation of research results - which should be in direct comparison with the relevant literature.

While on the one hand the computerization of databases and the use of software and other applications have provided notable advances in collection methods, on the other the progresses in interpreting the extracted material still seem quite timid. There are several proposals in Political Communication in Brazil that, with the excuse of investigating events related to network communication technologies, for example, are satisfied in counting number of hashtags, posts or followers.

In other words, if metadata gathering tools can contribute to broadening the possibilities of empirical analysis - avoiding data processing to be manually executed - this does not mean that the researches draw conclusions that bring advances to the understanding of the state of the art. This is the case of apparently sophisticated network analyzes that, by using graphs or by focusing on relations between "influencers" and "influenced" users, are little concerned with reflecting on the real effects of digital media use on political decisions, for example. In saying so, this essay does not intend to devalue the information raised in such investigations; the problem refers rather to the impression that a relevant portion of the studies that dominate such resources could use the data collected more productively in order to establish a confrontation that goes beyond mere illustrations (Recuero, Zago \& Bastos, 2014).

There are also works intended to set up a robust research design but that result in a type of argument that privileges the method itself (the collection design, for example), 
to the detriment of the investigated problem itself. Again, the intention here is not to depreciate the fact that, on some occasions, descriptions are necessary as the first step towards a mapping that will allow (in later stages) more consistent findings. The question is: from what moment do we consider such an inventory of phenomena to be sufficient, in order not to repeat ad infinitum illustrations of cases that often do little to broaden our understanding of the objects analyzed?

\section{FAILURES IN THE PROCESS OF SETTING UP AND APPLYING METHODOLOGICAL STRATEGIES}

Still bound to the methodological discussion, a recurrent polemic in the studies in Political Communication in Brazil (in fact, it permeates the Human and Social Sciences in the country) refers to the dispute between researchers that emphasize quantitative or qualitative methods. If the research in the area has evolved to the point of realizing that the two approaches are not antagonistic (Cervi, 2009), the most recent effort has ratified the idea that certain starting questions can only be answered if the range of techniques selected to conduct the study is consistent with the research problem.

Let us take the case of an investigation about the tensions that mark the backstage of the interactions between political coordination and marketing consultants that work for a same electoral campaign (Marques \& Carneiro, 2018). In this case, in-depth interviews would be one of the few alternatives capable of responding to such concerns - and there would be little point in insisting on the use of quantitative methods if only direct interaction with the agents involved in the process can help to reveal attitudes and perspectives of the participants (Barakso, Sabet \& Schaffner, 2014). In this kind of research, methodological rigor should address questions about how to ensure the representativeness of respondents and the transparency of primary data (making interview transcripts publicly available, for example).

In addition, one acknowledges the existence of researches that claim quantitative character (willing to present tables and graphs of the most diverse formats), but which, in the end, are limited to counting frequencies (indicating how many times certain terms appear in a sample, for example) (Grijó \& Vieira, 2017). Criticism thus turns over those cases that only emphasize the description of the data collected - and their limited contribution to illustrate what occurred in a situation (Andrade, 2014).

A consistent quantitative analysis starts from the distinctions between dependent and independent variables, and (a) is able to evaluate possible correlations between these variables; (b) reflects on the relevance of the indexes to be checked and compared; (c) separates the most relevant variables for the explanation of a given problem (avoiding spurious regressions and assigning weights to essentially different factors); (d) speculates about the degree of mutual influence between variables, to avoid duplication when we measure the effects. These aspects are not always covered by the investigations of our expertise.

Let us analyze the case of studies that call themselves "quantitative" by using categories (whether they are based on literature or constructed inductively) which are 
willing to evaluate, for example, the content of political communication pieces. In different works (Marques, Silva \& Matos, 2012), it is noticed that there is no evident concern in constructing the indexes considering the major (or minor) proximity (or even overlapping) of the own typologies proposed. The result sometimes refers to taxonomies in which form, function and content of agents and agendas are confused - not to mention the high numbers of the category "others", which focuses on situations not included in the initially proposed indicators.

It should be noted at this point that there are methodological procedures that do not depend on the development of new techniques. Here again the importance of being transparent about the use of data collection, analysis and interpretative methods deserves a careful consideration: How steps were followed during the content classification? How many researchers took part in the process? Was the team responsible for cataloging and rating trained? Was there a reliability test? What was done in case of divergence among researchers throughout the categorization process? If the classification was solely made by a single investigator, the risks of a subjective analysis could compromise the consistency of the results?

Such responses should include the availability of the databases and codebooks used for categorization, which would allow other researchers to replicate the procedures as well as check for possible inconsistencies. In this sense, this paper draws attention to a fact pointed out by Gary King (2006) for more than a decade: several journals (including those in Humanities and Social Sciences) have adopted policies of sharing raw data and invested in norms that encourage readers to replicate the results of the articles they publish. In short, not only the works of Political Communication, but also any scientific work should prevent the reader or evaluator from having to rely on the researcher's word.

\section{CONSEQUENCES OF THEORETICAL-METHODOLOGICAL PROBLEMS}

The theoretical and methodological difficulties of some of the Brazilian articles on Political Communication can be verified in their respective conclusions. At least three problems stand out in the results of different researches on media and democracy: exaggeration about the effects of mass communication on the audience; generalization of the findings (discoveries on specific cases do not always apply to a more comprehensive corpus); and a kind of ideological persecution syndrome, aligned with the idea of "hostile media perception" (Vallone, Ross \& Lepper, 1985).

\section{THE QUESTION OF HYPERMIDIATISM AND THE GENERALIZATION OF THE CONCLUSIONS}

The good quality of an empirical investigation is measured through the updated and plural literature that the work employs, as well as through the its empirical procedures to examine a certain phenomenon, object or corpus. In addition, the discussion provided after the presentation of the data is also imperative to convince the reader that the findings are compelling. At this point, an additional hindrance becomes noticeable in the area of expertise examined here. 
In several opportunities, the study of the use of a specific communication platform (or the empirical approach to a particular actor or institution) frequently serves to achieve broader conclusions. This phenomenon is more easily verified in papers dedicated to electoral communication. For example, if a given candidate was defeated, this would be due to misuse of communication strategies - whether the margin of defeat was minimal or whether there are other factors associated with the context, campaign agenda or voter behavior, as Figueiredo (2008) and Moisés (2008) have pointed out.

Depending on the case, the study of a simple Instagram profile is the object used to identify the overall tone of a campaign or even to explain why the election was successful (or not) for a candidate. One points, therefore, to the need to avoid a "hyper-mediatic" perspective, since not everything from the electoral point of view is limited to the construction of image; not always microphenomena are sufficient to explain victories and defeats in the dispute for the vote. Thus, it is fundamental to adopt a position that recognizes the limitations of the research findings themselves - which does not always occur in the research tied to the area of expertise here examined.

\section{THE IDEOLOGICAL PERSECUTION SYNDROME}

It is necessary to discuss if and to what extent an ideological-party influence is verified in studies linked to the area of Political Communication in Brazil. It should be noted, before proceeding with the argument, that this is not a matter of criticizing the authors themselves (or even the party preferences that they may legitimately have). Our aim in this topic is to invest in efforts able to avoid an interpretation of the phenomena mixed with the defense of a political guideline.

In practice, it should be said that there is no novelty in affirming (or even denouncing, depending on the mood) that a specific media company has editorial preference for a political party or ideology. Indeed, we have witnessed newspapers clearly supporting candidates, as it happened to Folha de S. Paulo in 2000, when it endorsed Marta Suplicy (Labours Party) in the run for São Paulo City Hall (Marta X Maluf, 2000, 15 October, p. A2); or the case of the newspaper O Estado de S. Paulo, which opted for José Serra in the 2010 presidential elections (Editorial: O mal a evitar, 2010, 26 September, p. A3).

Moreover, not all works observe the particularities of newspapers routines such as: (a) the position of the writers against a particular party can be clear and textual, since some of them are affiliated to political or social movements (what does not mean that they defend the same editorial position typically hold by the newspaper); (b) there are circumstances in which the audience may not fully understand the boundaries between news and opinion. But what we frequently deal with are academic texts that find obstacles even to differentiate the news coverage from editorial coverage.

This article is not advocating in favor of the idea that (1) the owner or the majority shareholders of media companies do not head the daily agenda-setting; (2) nor are we denying that there is no synchrony between news and editorial agendas (Marques, Miola, Mitozo \& Mont'Alverne, 2017); nor is it being denied that journalists themselves 
may also prefer to give voice to sources they ideologically consider most appropriate; and, finally, we are not underestimating the political influence that the media have over the audience (Eilders, 1999; McKnight, 2010). The argument here is simple: in the Brazilian case, much of the criticism about performance or bias adopted by the media (Chaui, 2006) is more a premise than the result of a empirically substantiated conclusion.

More often asserted than tested (i.e., a story, not science), negative media effects achieved the status of national myth in the country that produced both the real William Randolph Hearst ("You furnish the pictures; I'll furnish the war": 1897) and his fictional apotheosis, Citizen Kane ("People will think... what I tell them to think": 1941). (Hartley, 2015, p. 852)

These findings are not intended to invalidate the efforts made to identify "out of the political scene" interests (Gomes 2004). The argument of this paper, in fact, is in tune with Luis Felipe Miguel's one, when the author focuses on studies based on the technique of valence:

I do not believe that it is necessary [when discussing the valence of journalistic coverages] (...) to invalidate the idea that there is bias in the news. (...). The way forward is precisely to advance in a more complex understanding, preventing the weaknesses of the use of valence to compromise our ability to make a grounded critique of the political action of the media. (Miguel, 2015, p. 175)

This "more complex understanding" probably refers to the importance of admitting that journalism has its own production routines, i.e. dynamics that are not always limited to political action alone; or to consider the existence of political activity sponsored by media companies without matching it directly with political parties, as Biroli points out (2013).

In addition, Azevedo (2010) shares a similar assessment by pointing out the need to produce more substantive explanations so that it might be possible to measure the degree of partisanship in the case of Brazilian Journalism:

respecting the legitimate democratic choice of each press vehicle to choose one of the candidates in competition, the question to be answered is whether the LP [Labors Party] and its presidential candidate since 1989 (Lula) received a balanced treatment and on an equal footing with his main political opponents. (...) If the answer is no, it is necessary to produce a consistent explanation that goes beyond the conspiracy theory of the "ruling classes" against LP or the simple realization that the DNA of the media is conservative and period. (Azevedo, 2010, p. 50)

Thus, if the editorial influence of media owners cannot be ruled out, it remains fundamental to understand to what extent the institution negotiates with the fact that there are principles, skills and abilities fostered during the professional training journalists 
receive (Fausto Neto, 2008). Finally, as said before, one cannot ignore the production routines that have being carefully considered by journalism research.

More directly, we ask: do the news stand in favor of a political position so clear as claimed by texts dedicated to denouncing the coverage bias? Is it possible to assert that the degree of luminosity of a photograph is intended to emphasize the presence of a political authority? Will the angle chosen by the photographer produce the same interpretative effect over the audience? It does not seem appropriate, then, to assume - without a proper empirical treatment - which would be the intentions of the messages' producers. It is also reckless to generalize the effects of media products on different parts of the public, as Mundim (2014) says.

At this stage, it is legitimate to query whether there is a risk that the research work on Political Communication will not perceive its own bias. Such a stance, by the way, is also criticized even by authors with political-party actions, as indicated below: "Florestan Fernandes, when discussing 'on theoretical work', observes that 'an intense militant activity is incompatible with academic life... (...) Politics breaks the intellectual isolation, but its continuous exercise pushes us to the pragmatic reasons inherent in them" (Ortiz, 1990, p. 173).

In this landscape, it is common that research results in the field of Political Communication are used by political parties in order to ratify a world perspective to be shared by militants (Labors Party, 2015).

To finish this topic, it is possible to point out another analytical damage if the party alignment here discussed is confirmed: the regular and commonly accepted circulation of "accurate" diagnoses about the political effects of the media seems to be exempted from more rigorous evaluation (precisely because they bring a convenient political panorama). This is a relevant problem, especially if there is resistance in accepting (when evaluating articles and projects) the study of agendas or institutions that are considered as "conservative". It would be harmful to the research environment to diminish studies that contemplate institutions considered as "enemies" by a portion of the research field.

\section{CONCLUSION: PROSPECTS FOR IMPROVEMENT}

Walter Lippmann's book Public Opinion (1922/2008) is considered by different scholars as one of the forerunners of the studies in Political Communication. Since the very beginning of the investigations we are discussing, researchers said to seek a "critical" position in the way they assess the performance of mass communication. Regarding the roles of professionals and journalistic companies, as well as the work dynamics of spin doctors and other agents dedicated to the construction of public images, the fact is that caveats associated to media bias now reverberate not only between the scholars of Political Communication, but also comes from non-specialists.

There is something positive about this: a greater share of the citizens follows more closely the products and the agents of the media politics, being more attentive to the journalistic coverage, the content of the electoral programs and the performance of the 
candidates during the debates. On the other hand, it should be noted that such a willingness to continually evaluate (and often, without knowing the parameters or procedures used by media professionals) the performance of the media system seems to highlight the need for studies in Political Communication in Brazil to become a reference for citizens.

We must highlight that it is not being suggested that the field should close itself to external evaluations, nor the idea is to censor the flaws presented by non-specialists. What we suggest is the need for literature to stop circling around itself. Even almost 30 years after the Brazilian redemocratization, many of the original questions were not left behind - what can be proved by examining our repetitive methodological strategies and our weakness in consolidating the social authority of our discipline.

In order to conclude this article, our intention is now to address two additional closely related issues that serve as suggestions to help solving some of the obstacles we bring into account. The first of these issues refers to the need to refine the articulation of Political Communication projects with neighboring scientific specialties. Furthermore, we stress the role of scientific associations as key institutions in the task of sponsoring the broadening of research boundaries in the area.

\section{THE LACK OF ARTICULATION WITH NEIGHBORING SPECIALTIES}

A persisting problem in our area of expertise is linked to the resistance to integrate Political Communication with studies of bordering areas - for instance, the option to neglect the contributions offered by the Political Economy of Communication (Rothberg, Napolitano \& Stroppa, 2016).

Hallin \& Mancini's book (2004) represents an emblematic reference because it associates a discussion associated to the communication market's landscape in different countries to the strategies of political communication employed by diverse actors. Another important scholar who advocates for the approximation between the competences of Political Economy and Political Communication is Papathanassopoulos (2015, p. 770), when he states that:

in effect, there is a critical relation between media policy on the one hand, and political communication on the other. These distinct processes of exercising power feed into one another and, provided there is a balance of power, they mutually determine one another to the benefit of the public interest.

Maintaining a closer dialogue with the literature on Political Economy of Communication (for example, as provided by Lattman-Weltman \& Chagas (2016)) would open the opportunity to include in our agenda topics such as the power of telecommunications companies on the new business models - which affects from the financing of electoral campaigns to journalistic practices. A relevant challenge, therefore, lies in rejecting our permanence in areas of epistemological comfort.

The investments in serious analyses of visual contents can be included in the same path of resistance perceived in the studies of Political Communication. Once more, this 
is a result of the lack of dialogue with theories dedicated to assessing media images. The few movements in this direction are associated with discourse analysis or are originated from the Semiotics legacy to propose controversial analyses of the relationship between text and image. It is important to mention that sometimes the works in our field of studies do it in a fragmented way, separating the two types of content - text and image into different articles and thereby compromising the full understanding of the message. Then, we should foster a greater integration between methodologies that aim to cover the same set of objects.

\section{THE ROLE OF SCIENTIFIC ASSOCIATIONS AND JOURNALS IN THE RESEARCH AGENDA}

The role of associations and scientific congresses in Political Communication cannot be disregarded concerning the incentive to cultivate epistemological debates. For example, round tables able to give voice to journal editors are essential. In such opportunities, the authors could know more not only about the desirable characteristics that feature the articles that get published (or understand the most recurrent faults pointed out in refused submissions), but also to verify the degree of transparency of the evaluation processes (what would contribute to professionalize the scientific field). Listening to the editors is fundamental since they have contact with the most recent productions - what could make them to reveal which research agendas need more investment.

Taking advantage of scientific meetings to promote clarifications, cooperation and clashes on good science would open the opportunity for issues that have hitherto attracted little attention - but which are important - to be debated in depth. Among the issues that are still under-explored (and which could be targeted by dossiers, for example) are: the increasing use of activists to criticize political enemies through profiles on digital social networks; the particularities that feature the consumption of political information simultaneously through multiple screens; the comparison between news and opinion dimensions on newspapers to understand if (and to what extent) there is a bias.

The fundamental argument is now outlined, so it is time to elaborate two final considerations.

In the first place, we ask: to what extent do the problems verified in part of the research conducted in Brazil are repeated in other democracies? If it is true that the institutional guidelines (whether of the political system or the media system) or the characteristics of the national political culture influence the most recurrent research interests, we must stress that the problems previously mentioned are not exclusive to the Brazilian literature in Political Communication. Thus, even if they imply variations, critiques related to the field of Media Studies mentioned here are repeated in other social, political and intellectual contexts (Blumler, 2016).

Based on this, Kaid and Strömbäck (2008) call for the need to create measurement parameters to be used by researchers interested in comparing cases from different countries. Esser and colleagues point out the difficulties entailed by conceptual inaccuracies and reflect on how this reverberates in the operationalization of comparative variables: 
... despite all progress, research on political news journalism faces some serious challenges related to a lack of conceptual clarity as well as insufficient comparability across studies and cumulativity of findings. (...) While many scholars use similar theoretical concepts, the conceptualizations and, in particular, operationalizations often differ. (Esser et al., 2011, p. 140)

Such reflections prove that the problem outlined throughout this article does exist, and that it is not limited to the Brazilian scientific production. In this sense, the essential concern here is to provoke debate in order to know how attentive Brazilian researchers are to such problems and whether these researchers are willing to challenge them.

Finally, over the last ten years the profile of the material produced by researchers in the field of Political Communication has improved - mainly due to the greater exigences of the evaluation processes of postgraduate programs in Brazil. However, this does not prevent us from pointing out that there are persistent barriers to a consistent accumulation of methodologies and knowledge, as well as to increase the insertion of our research in the international arena - a persistent obstacle that goes beyond language barriers.

Translated by Isabele Mitozo

\section{BIBLIOGRAPHIC REFERENCES}

Albuquerque, A. (1999). Aqui você vê a verdade na tevê: A propaganda política na televisão. Niterói: Universidade Federal Fluminense.

Albuquerque, A. (2013). Media/politics connections. Media, Culture Q Society, 35(6), 742-758. doi: $10.1177 / 0163443713491302$

Aldé, A., Chagas, V. \& Santos, J. G. B. (2013). Teses e dissertações defendidas no Brasil (1992-2012): um mapa da pesquisa em comunicação e política. Revista Compolítica, 3(2), 7-43. doi: 10.21878/ compolitica.2013.3.2.43

Andrade, D. S. (2014). A comunicação governamental da presidente Dilma Rousseff: uma análise de conteúdo do portal da Presidência da República. Comunicação e Sociedade, 26, 191-206. doi: 10.17231/ comsoc.26(2014).2033

ANPOCS, Associação Nacional dos Programas de Pós-Graduação em Ciências Sociais. (2018). Encontros Anteriores. São Paulo: ANPOCS. Retrieved from http://www.anpocs.com/index.php/encontros/ encontros-anteriores

Azevedo, F. (2010). A imprensa brasileira e o PT: um balanço das coberturas das eleições presidenciais (19892006). Revista ECO-Pós, $12(3), 48-65$.

Barakso, M., Sabet, D. \& Schaffner, B. (2013). Understanding political science research methods. London: Routledge. doi: 10.4324/9780203801253

Bardin, L. (2007). Análise de conteúdo. Lisbon: Edições 70.

Biroli, F. (2013). Limites da política e esvaziamento dos conflitos: o jornalismo como gestor de consensos. Revista Estudos Políticos, 6, 144-161. 
Blumler, J. (2016). Political Communication. In G. Mazzoleni, K. Barnhurst, K. Ikeda, H. Wessler \& R. Maia (Eds.), The international encyclopedia of political communication (pp. 1-9). London: Wiley-Blackwell. doi: 10.1002/9781118541555.wbiepc213

Bohman, J. (1996). Public deliberation: Pluralism, complexity, and democracy. Cambridge: MIT Press. doi: $10.5860 /$ choice. $34-5341$

Bresser-Pereira, L. (2017). The political construction of Brazil: society, economy, and State since independence. Boulder: Lynne Rienner Publishers.

Campos, L. (2014). A identificação de enquadramentos através da análise de correspondências. Opinião Pública, 20(3), 377-406. doi: 10.1590/1807-01912014203377

Canavilhas, J. (2010). Do gatekeeping ao gatewatcher: o papel das redes sociais no ecossistema mediático. In Nuevos medios, nueva comunicación - Livro de atas do II Congreso Internacional Comunicación 3.0 (pp. 1-12). Salamanca: Universidad de Salamanca. Retrieved from http://campus.usal. es/ comunicacion3puntoo/comunicaciones/o61.pdf

CAPES, Coordenação de Aperfeiçoamento de Pessoal de Nível Superior. (2017). Relatório da Avaliação Quadrienal 2017: Comunicação e Informação. Brasília, CAPES. Retrieved from http://capes.gov.br/ images/stories/download/avaliacao/relatorios-finais-quadrienal-2017/20122017-Comunicacaoquadrienal.pdf

Carvalho, R. (1999). Transição democrática brasileira e padrão midiático publicitário da política. Campinas: Pontes.

Cervi, E. (2009). Métodos quantitativos nas ciências sociais: uma abordagem alternativa ao fetichismo dos números e ao debate com qualitativistas. In J. Bourguignon (Ed.), Pesquisa Social (pp. 125-143). Ponta Grossa: Toda Palavra.

Charaudeau, P. (2006). Discurso político. São Paulo: Contexto.

Chaui, M. (2006). Simulacro e poder: uma análise da mídia. São Paulo: Fundação Perseu Abramo.

Citelli, A., Berger, C., Baccega, M., Lopes, M. \& França, V. (Eds.) (2014). Dicionário de Comunicação: escolas, teorias e autores. São Paulo: Contexto.

Compolítica, Associação Brasileira de Pesquisadores em Comunicação e Política. (2018). Diretório de Teses e Dissertações. Rio de Janeiro: Compolítica. Retrieved from http://compolitica.org/diretorio/index.php/ diretorio/catalog

Compós, Associação Nacional dos Programas de Pós-graduação em Comunicação. (2018). Anais. Brasília: Compós. Retrieved from http://www.compos.org.br/anais_encontros.php

Correia, J. C. (2005). Recensão do livro Comunicação e política: conceitos e abordagens, de A. A. C. Rubim. Media QJornalismo, 7, 137-147.

Duarte, J. (Ed.). (2012). Comunicação pública: Estado, mercado, sociedade e interesse público. São Paulo: Atlas.

Editorial: O mal a evitar (2010, 26 de setembro). O Estado de São Paulo, p. A3.

Eilders, C. (1999). Synchronization of issue agendas in news and editorials of the prestige press in Germany. The International Journal of Communications Research, 24(3), 301-328. doi: 10.1515/comm.1999.24.3.301

Elster, J. (Ed.) (1998). Deliberative democracy. Cambridge: Cambridge University Press. doi: 10.1017/ cbog781139175005 
Entman, R. (1993). Framing: toward a clarifcation of a fractured paradigm. Journal of Communication, 43(4), 51-58. doi: 10.1111/j.1460-2466.1993.tbo1304.x

Esser, F., Strömbäck, J. \& De Vreese, C. (2012). Reviewing key concepts in research on political news journalism. Journalism, 13(2), 139-143. doi: 10.1177/1464884911427795

Fairclough, N. (2001). Discurso e mudança social. Brasília: Universidade de Brasília.

Fausto Neto, A. (2004) Discurso político e mídia. In A. A. Rubin, (Ed.). Comunicação e política: conceitos e abordagens (pp. 105-125). Salvador: Edufba.

Fausto Neto, A. (2008). Notas sobre as estratégias de celebração e consagração do jornalismo. Estudos em Jornalismo e Mídia, 5, 17-29. doi: 10.5007/1984-6924.2008v5nipiog

Fernandes, C. M. \& Correia, G. C. (2014). Mídia jornalística como instrumento de ação política no Golpe Militar de 1964. Estudos em Jornalismo e Mídia, 11(1), 77-88.

Figueiredo, C. D. \& Mendes, A. R. S. (2015). Roteiros para dispositivos de mídias móveis: tela, tempo e trânsito como elementos contingentes. Revista GEMInIS, 6(2), 165-182.

Figueiredo, M. (2008). A decisão do voto. Belo Horizonte, Editora UFMG.

Foucault, M. (1979). Microfisica do Poder. Rio de Janeiro: Graal.

Gamson, W. \& Modigliani, A. (1989). Media discourse and public opinion on nuclear power. American Journal of Sociology, 95(1), 1-37. doi: 10.1086/229213

Gamson, W. (1992). Talking politics. Cambridge: Cambridge University Press.

Giacomini Filho, G. (2013). Publicidade: possibilidades para um receptor interativo. In A. Pessoni \& P. F. Perazzo (Eds.), Neorreceptor no fluxo da comunicação (pp. 15-32). Porto Alegre: EdiPUCRS.

Goffman, E. (1986). Frame analysis: an essay on the organization of experience. Boston: Northeastern University Press.

Gomes, A. L. \& Torres, J. V. C. (2017). Nos labirintos do discurso: agendamento e procedimentos de exclusão nos títulos da Folha, Globo e Estadão. Comunicação Q Inovação, 18(36), 68-78.

Gomes, W. \& Maia, R. (2008). Comunicação e democracia: problemas e perspectivas. São Paulo: Paulus.

Gomes, W. \& Moreira, S. V. (2000). O estado da arte dos cursos brasileiros de pós-graduação em Comunicação (entrevista). Revista Brasileira de Ciências da Comunicação, 23(2), 121-136.

Gomes, W. (2003). O estranho caso de certos discursos epistemológicos que visitam a área de Comunicação. In M. Lopes (Ed.), Epistemologia da Comunicação (pp. 313-330). São Paulo: Loyola.

Gomes, W. (2004). Transformações da política na era da comunicação de massa. São Paulo: Paulus.

Grijó, W. P. \& Vieira, I. G. (2017) Visibilidade comunicativa na internet: uma análise da fan page de Marcelo Freixo. Comunicação \& Informação, 20(3), 64-83.

Guareschi, P. (1994). Comunicação e poder: presença e o papel dos meios de comunicação. São Paulo: Vozes.

Guerra, J. (2014). Transparência editorial. Revista Latinoamericana de Ciencias de la Comunicación, 11, 196-209.

Gutmann, A. \& Thompson, D. (1996). Democracy and disagreement. Cambridge: Harvard University Press. 
Habermas, J. (1996) Between facts and norms: contributions to a discourse theory of law and democracy. Cambridge: Polity Press.

Hallin, D. \& Mancini, P. (2004). Comparing media systems. Cambridge: Cambridge University Press. doi: $10.1017 / \mathrm{cbog780511790867}$

Hartley, J. (2015). Narrative, political. In G. Mazzoleni, K. Barnhurst, K. Ikeda, H. Wessler \& R. Maia (Eds.), The international encyclopedia of political communication (pp. 849-857). London: Wiley-Blackwell. doi: 10.1002/9781118541555.wbiepc137

Kaid, L. L. \& Strömbäck, J. (2008). Election news coverage around the world. In J. Strömbäck \& L. L. Kaid (Eds.), The handbook of election news coverage around the World (pp. 421-431). New York: Routledge. doi: $10.4324 / 9780203887172$

King, G. (2006). Publication, publication. Political Science Q Politics, 39(1), 119-125. doi: 10.1017/ s1049096506o6o252

Lattman-Weltman, F. \& Chagas, V. (2016). Mercado futuro: a economia política da (re)partidarização da imprensa no Brasil. Dados, 59, 323-356. doi: 10.1590/00115258201679

Liedtke, P. F. (2008). Governando com a mídia: os presidentes e o uso político dos meios de comunicação de massa. Comunicação Q Inovação, 9(16), 32-41.

Lima, V. A. (1997). Políticas regionais de comunicação: novos atores, velhos problemas. In I. Lopes \& J. Marques de Melo (Eds.), Políticas regionais de comunicação: os desafios do Mercosul (pp. 133-143). Londrina: Intercom.

Lippman, W. (1922/2008). Opinião pública. Petrópolis: Vozes.

Maia, R. (2006). Mídia e vida pública. In R. Maia \& M. Castro (Eds.), Mídia, esfera pública e identidades coletivas (pp. 11-45). Belo Horizonte: Editora UFMG.

Maia, R. (2012). Deliberation, the media and political talk. New York: Hampton Press.

Marques, F. P. J. \& Carneiro, A. (2018). Corações, mentes e estratégias: a relação entre "marqueteiros" e políticos durante as eleições de 2012 em Fortaleza. Revista de Sociologia e Política, 26(65), 105-131. doi: $10.1590 / 1678-987317266507$

Marques, F. P. J. (2006). Debates políticos na internet: a perspectiva da conversação civil. Opinião pública, 12(1), 164-187. doi: 10.1590/So104-62762006000100007

Marques, F. P. J., Silva, F. W. \& Matos, N. (2012). Estratégias de comunicação política online: uma análise do perfil de José Serra no Twitter//Political campaigns and online strategies: the case of the 2010 Brazilian elections. Contemporanea - Revista de Comunicação e Cultura, 9(3), 344-369.

Marques, F. P. J., Miola, E., Mitozo, I. \& Mont'Alverne, C. (2017). Um estudo comparativo entre as agendas políticas dos jornais Folha de S. Paulo e O Estado de S. Paulo nas seções opinativa e informativa. $41^{\circ}$ Encontro Anual da ANPOCS - Livro de atas do $41^{\circ}$ Encontro Anual da Associação Nacional de PósGraduação e Pesquisa em Ciências Sociais (pp. 1-26), Caxambu: ANPOCS.

Marques, F. P. J., Vimieiro, A.C.S.C., Vieira, A. C. R \& MELO, S.B.C. (2009). O fórum na tela: eleições, debates televisivos e deliberação mediada. Contemporanea, 7(1), 1-28.

Marta X Maluf (2000, 15 de outubro). Folha de S. Paulo, p. A2.

Matos, H. (1994). Mídia, eleições e democracia. São Paulo: Scritta. 
Matos, H. (Ed.) (2012). Comunicação pública: interlocuções, interlocutores e perspectivas. São Paulo: ECA/USP.

McCombs, M. E. \& Shaw, D. (1972). The agenda-setting function of mass media. Public Opinion Quarterly, 36(2), 176-187. doi: $10.1086 / 267990$

McKnight, D. (2010). A change in the climate? The journalism of opinion at News Corporation. Journalism, 11(6), 693-706. doi: 10.1177/1464884910379704

Melo, J. M. de (1999). A produção acadêmica brasileira em comunicação. Revista Famecos, 6(11), 7-26. doi: $10.15448 / 1980-3729.1999 .11 .3048$

Miguel, L. \& Biroli, F. (2010). Mídia, representação e democracia. São Paulo: Hucitec.

Miguel, L. (2015). Quanto vale uma valência? Revista Brasileira de Ciência Política, 17, 165-178. doi: $10.1590 / 0103-335220151706$

Miguel, L. F. \& Biroli, F. (Eds.) (2010). Mídia, representação e democracia. São Paulo: Hucitec.

Miola, E. (2009). Deliberação online em ambientes institucionais: um estudo do fórum de discussão do portal da Câmara dos Deputados. Contemporanea, 7(2), 1-24.

Moisés, J. (2008). Cultura política, instituições e democracia. Revista brasileira de ciências sociais, 23(66), 11-43. doi: $10.1590 /$ so102-69092008000100002

Moragas, M. (1981). Teorías de la comunicación. Barcelona: Gustavo Gili.

Mundim, P. (2014). Cobertura da imprensa e eleições presidenciais de 2006. Revista Brasileira de Ciências Sociais, 29, 91-107. doi: 10.1590/s0102-69092014000300007

Orlandi, E. (2007). Análise de discurso. Campinas: Pontes.

Ortiz, R. (1990). Notas sobre as ciências sociais no Brasil. Novos Estudos, 27, 163-175.

Papathanassopoulos, S. (2015). Media policy. In G. Mazzoleni, K. Barnhurst, K. Ikeda, H. Wessler \& R. Maia (Eds.), The international encyclopedia of political communication (pp. 1-9). London: Wiley-Blackwell. doi: $10.1002 / 9781118541555$.wbiepcog4

Partido dos Trabalhadores. (2015). Globo: 50 anos de manipulação. Brasília. Retrieved from http://www.pt.org. br/globo-5o-anos-de-manipulacao/

Paulino, F. P., Guazina, L. \& Oliveira, M. (2016). Serviço público de média e comunicação pública: conceito, contextos e experiências. Comunicação e Sociedade, 30, 55-70. doi: 10.17231/comsoc.30(2016).2485

Pêcheux, M. (1988). Semântica e discurso. São Paulo: Unicamp.

Peruzzo, C. M. K. (2003). Mídia local e suas interfaces com a mídia comunitária. In M. Ledo, X. López \& M. Salgueiro (Eds.), Anuário internacional de comunicação lusófona (pp. 141-162). São Paulo: LUSOCOM.

Recuero, R., Zago, G. \& Bastos, M. T. (2014) O discurso dos\# ProtestosBR: análise de conteúdo do Twitter. Galáxia, 28, 199-216. doi: 10.1590/1982-25542014217911

Rede Globo. (2018). Debate collor x Lula. Retrieved from http://memoriaglobo.globo.com/erros/debatecollor-x-lula.htm

Rothberg, D., Napolitano, C. J. \& Stroppa, T. (2016). Direito, sociedade e comunicação: um exame do anteprojeto de lei da mídia democrática no Brasil. Comunicação a Informação, 30, 87-102. doi: 10.17231/ comsoc.30(2016).2487 
Rubim, A. (Ed.) (2004). Comunicação e política. Salvador: Edufba.

Sampaio, A. (2010). Um novo cenário na TV aberta brasileira. Encontro de estudos multidisciplinares em cultura - Livro de Atas do VI ENECULT (pp. 1-15). Salvador: FACOM/UFBA.

Santos, J. G. B., Aldé, A. \& Schwambach, A. C. F. (2016). Panorama das teses e dissertações brasileiras envolvendo internet e política de 1995 a 2014. $40^{\circ}$ encontro anual da ANPOCS - Livro de atas do $40^{\circ}$ Encontro anual da Associação Nacional de Pós-Graduação e Pesquisa em Ciências Sociais (pp. 1-27). Águas de Lindóia: ANPOCS.

Seridorio, D. F. \& Luvizotto, C. K. (2017). Internet como espaço de deliberação e participação política. Comunicação Q Sociedade, 39(3), 79-110.

Silva, G. (2009). De que campo do jornalismo estamos falando? Matrizes, 3(1), 197-212.

Sokal, A. \& Bricmont, J. (2010). Imposturas intelectuais. Rio de Janeiro: Record.

Sousa, C. H. P. \& Marques, F. P. J. A. (2015). Wikipédia, democracia e eleições municipais em São Paulo: um estudo sobre as edições de verbetes durante a campanha eleitoral de 2012. RECIIS. Revista Eletrônica de Comunicação, Informação Q Inovação em Saúde, 9(2), 1-25. doi: 10.29397/reciis.vgi2.940

Vallone, R., Ross, L. \& Lepper, M. (1985). The hostile media phenomenon. Journal of Personality and Social Psychology, 49, 577-585. doi: 10.1037//0022-3514.49.3.577

Van Dijk, T. A. (2008). Discurso e poder. São Paulo: Contexto.

Vimieiro, A. \& Maia, R. (2011). Análise indireta de enquadramentos da mídia. Revista Famecos, 18(1), $235-252$. doi. 10.15448/1980-3729.2011.1.8810

Weber, M. H. (1990). Pedagogias de despolitização e desqualificação da política brasileira (as telenovelas da Globo nas eleições de 1989). Comunicação Q Política, 1, 67-84.

Weber, M., Coelho, M. \& Locatelli, C. (Eds.) (2017). Comunicação pública e política. Florianópolis: Insular.

\section{ACKNOWLEDGEMENTS}

The authors are grateful to Camila Mont'Alverne, Isabele Mitozo, and Paulo Ferracioli for criticizing the main arguments that we outlined here. Moreover, Isabele Mitozo was responsible for translating the article to its English version. We thank to all the institutions that provided funding for this research, namely CAPES and CNPq.

\section{BIOGRAPHICAL NOTES}

Francisco Paulo Jamil Marques holds a PhD in Communication Studies and a Senior Lecturer in Politics at the Federal University of Paraná, Brazil. He works as a CNPq (Brazilian National Scientific Council) research fellow and coordinates the Research Group on Media, Politics, and Technology (PONTE). His interests focus on Political Communication, Journalism, Public Opinion, and Digital Democracy.

E-mail: marquesjamil@gmail.com

Address: Avenida Silva Jardim, 368, apto. 1503 
Rebouças, Curitiba, Paraná, Brasil

CEP: 80230-000

Edna Miola holds a PhD in Communication Studies (UFMG, 2012). Professor and researcher at Federal University of Technology-Paraná, Brazil. Areas of interest: Political Communication, Public Communication, and Public Opinion.

E-mail: ednamiola@gmail.com

Address: Avenida Silva Jardim, 368, apto. 1503

Rebouças, Curitiba, Paraná, Brasil

CEP: 80230-000

* Submitted: 30.11.2017

* Accepted: 15.03.2018 